\title{
Proposing a Conceptual Model of Corporate Reputation Associated with Relationship Marketing and Customer Loyalty
}

\author{
Faisal A. Albassami ${ }^{1}$, Saleh S. Alqahtani ${ }^{2} \&$ Mahmoud A. Saleh ${ }^{2}$ \\ ${ }^{1}$ Institute of Finance, Saudi Arabian Monetary Agency \\ ${ }^{2}$ Department of Marketing, College of Business Administration, King Saud University, Saudi Arabia \\ Correspondence: Faisal A. Albassami, PhD candidate, King Saud University; Institute of Finance, Saudi Arabian \\ Monetary Agency, Saudi Arabia. E-mail: falbassami@gmail.com
}

\author{
Received: September 7, $2015 \quad$ Accepted: October 2, $2015 \quad$ Online Published: November 30, 2015 \\ doi:10.5539/ijms.v7n6p102 URL: http://dx.doi.org/10.5539/ijms.v7n6p102
}

\begin{abstract}
Based on the theory of reasoned action and Money and Hillenbrand's call to study corporate reputation in light of its antecedents and consequences, this article proposes a model in which corporate reputation is a core variable. The proposed model depicts relationship marketing as an independent variable, customer loyalty as a dependent variable, and the cognitive and affective factors of corporate reputation as mediating variables. This research is a conceptual contribution to global research on corporate reputation from the perspective of its implications on building marketing strategies and the positive consequences on a firm's performance.
\end{abstract}

Keywords: corporate reputation, relationship marketing, customer loyalty

\section{Introduction}

Historically, marketing has been about goods and, more recently, about services and brands (Balmer, 1998, 2001, 2006). Currently, marketing is going through another paradigm shift by focusing on factors and interactions at the corporate level. Balmer (2006) has labeled this perspective of marketing as "corporate marketing". This is also in agreement with the new American Marketing Association's 2007 definition of marketing: "marketing is the activity, set of institutions, and processes for creating, communicating, delivering, and exchanging offerings that have value for customers, clients, partners, and society at large". This new definition of marketing refers to marketing as "the activity" rather than an organizational function. The activity definition of marketing reflects that marketing is "an action word" (Hunt, 2010). Additionally, it points out that marketing is no longer solely the role of a marketing department, but rather an organization-wide responsibility (Hunt, 2010).

One of the major components of corporate marketing, and one that reflects activity in marketing, is what is called corporate reputation (Balmer \& Greyser, 2006; Abratt \& Kelyn, 2012). Corporate reputation is usually a consequence of the interactions between stakeholders and the firm over an extended period of time (Argenti \& Druckenmiller, 2004). Because stakeholders come from different walks of life, and each stakeholder group has distinct concerns and perspectives on the significant issues that the firm should be catered to, firms have different reputations as per each group of stakeholders (Abratt \& Kelyn, 2012).

Corporate reputation as a concept is related in marketing literature with a range of variables such as customer loyalty and relationship marketing. Accordingly, this study aims to review the marketing literature concerning the associations of these two variables with corporate reputation; the contribution of the researchers to the global literature is in the depiction of the antecedents and consequences of corporate reputation as a new trend in marketing that reflects marketing with an activity orientation.

\section{Corporate Reputation and Relationship Marketing}

Regarding corporate reputation, most scholars argue that reputation is a function of organizational behavior and relationships with stakeholders (Formbrun, 1996; Kim et al., 2013), both internal and external groups, including: employees, customers, suppliers, investors and local communities (Tischer \& Hildebrandt, 2014). Yet, scholars do not measure behaviors that stakeholders recall, nor the relationships nurtured with them. Corporate reputation is found mainly to be a by-product of management behavior and the quality of relationships formed with the general stakeholders (Yang, 2007; Yang \& Grunig, 2005). Accordingly, reputation can differ among the company stakeholder groups (Ali et al., 2015). Such findings strongly suggest that paying attention to building 
relationships with stakeholders will improve corporate reputation. It is important to note that corporate reputation can be managed only indirectly, through the nurture of relationships with the public.

Corporate reputation was defined as the: "collective representation of a firm's past actions and results" (Formbrun \& Van Riel, 1997; Kim et al., 2013). However, corporate reputation is reflected in the public relations literature as a function of one of the following elements: 1- Corporate marketing messages conveyed to stakeholders; 2- Experience with organizational behavior delivered to the stakeholders; and 3-informal messages amongst stakeholders (Grunig \& Hung, 2002). Corporate reputations are better formed by organizational activities and behavior, and corporate marketing messages alone cannot change the ways in which general stakeholders interpret these organizational activities (Grunig \& Hung, 2002).

Historically, scholars of corporate reputation believe that public relations manifest as a strategic messaging function that conveys messages to the public without taking a proactive step to direct the organization in strategically managing its corporate interactions with its stakeholders. However, it is only through such forethought to corporate behaviors that consistency is accomplished between what is done and what is said later to the public (Kim et al., 2013). In other words, managing corporate reputation is much more than messages communicated to the general stakeholders via mass media; rather reputation is shaped first through the behaviors of the firm.

The proliferation of new avenues of communication through social media has put pressure on even how firms should conduct themselves with the public in terms of their corporate behaviors and activities in building relationships with such external audiences (Kim \& Rhee, 2011).

\section{Research Gap}

Despite the literature on the importance of corporate behaviors and relationship building with stakeholders, very minimal research was found studying relationship marketing in relation to corporate reputation. In fact, when the question of how relationship marketing is related to corporate reputation is posed on Google Scholar, not a single paper was found (Kim et al., 2013). In addition, corporate reputation is minimally researched as an independent variable of an important customer response variable, namely customer loyalty.

\section{Building the Case for a Corporate Reputation Conceptual Model}

Reputation is mostly perceived as a significant intangible asset for the firm which helps to create value (Zabala et al., 2005; Roberts \& Dowling, 2002). In order to comprehend the value and the development process of reputation for any firm, researchers have studied corporate reputation in terms of its antecedents and consequences (Walsh \& Wiedmann, 2004; Money \& Hillenbrand, 2006). In figure 1, Money and Hillenbrand (2006) proposed the sequence of the antecedents and consequences of corporate reputation.

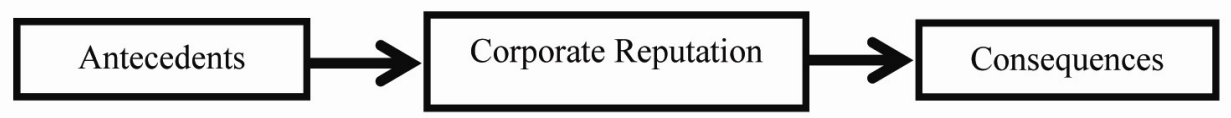

Figure 1. Antecedents and consequences of corporate reputation

The graphic sequence framework above helps to clarify how corporate reputation is formed and what value the firm gains from such a reputation. Without a profound understanding of the antecedents and consequences of corporate reputation, firms will not be able to build intangible assets and create value for customers (Money \& Hillenbrand, 2006). However, despite the fact that corporate reputation is studied at both personal and strategic levels, its antecedents and consequences as shown in table 1., there is a practical need to investigate the drivers that lead customers (a major stakeholder group) to form certain attitudes about firms which in turn lead to a consumer intending to behave and ultimately to final consumption behavior.

Money and Hillenbrand (2006) point out that this research gap has to be filled, and they emphasize the need for research at the personal stakeholder level (e.g., customer stakeholder group). One reason that corporate reputation should be studied extensively at the personal stakeholder level (e.g., customer stakeholder group) is that corporate reputation is understood and conceptualized as a perception construct in terms of how customers perceive past actions of the firm as well as an attitudinal construct regarding how generally appealing the firm is to the customers (Money \& Hillenbrand, 2006). 
Table 1. Antecedents and consequences of corporate reputation at the strategic and personal stakeholder levels

\begin{tabular}{llll}
\hline Level & Antecedents & Corporate Reputation & Consequences \\
\hline Strategic & Asset generating activities & Intangible assets & Market assets/performance \\
Personal & Observations and experiences & Beliefs and attitudes & Intentions and behaviors \\
\hline
\end{tabular}

Surveying the literature on corporate reputation and its antecedents and consequences, the researchers came across not a single study that looks at how relationship marketing acts as an antecedent of corporate reputation and its reflection on organizational performance, namely customer loyalty.

To fill this gap in the marketing literature, and from the above-mentioned discussion and framework proposed by Money and Hillenbrand (2006), the goal of this conceptual research is to evaluate the antecedents (Relationship Marketing) and consequences (Customer Loyalty) of corporate reputation from a customer perspective. Marketing researchers and scholars will be able to identify how customers form attitudes, develop a behavioral intention, and, finally, actualizing on their intention.

The researchers investigated - in answer to the call from Money and Hillenbrand, 2006-how customers experience and observe relationship marketing activities on the part of the firm and how that contributes to the formation of corporate reputation and, ultimately, leads to behavior on the part of the individual customer in the form of customer loyalty. The relationships among these factors are depicted in table 2.

Table 2. Customer's role in creating the reputation of the firm

\begin{tabular}{llll}
\hline Level & Antecedent & Corporate Reputation & Consequence \\
\hline Customer level & $\begin{array}{l}\text { Experience and observation of relationship Marketing } \\
\text { orientation }\end{array}$ & $\begin{array}{l}\text { Corporate reputation } \\
\text { (Customer-based) }\end{array}$ & Customer loyalty \\
\hline
\end{tabular}

\section{Theoretical Foundation}

As this research project aims to shed light on corporate reputation and how it is linked with relationship marketing (proposed antecedent) and customer loyalty (proposed consequence), it is important to note that the proposed inter-relationships and the integration of relationship marketing, corporate reputation and customer loyalty reflect not only conceptualization and framework of corporate reputation in light of antecedent (observation and experience), beliefs/ attitudes (corporate reputation), and consequence (intentions and behavior) thinking (Money \& Hillenbrand, 2006), but also go in parallel and in alignment with the theory of Fisbein and Ajzen (1975). Their reasoned-action theory shows how concepts such as beliefs, attitudes, intentions, and behaviors can be interrelated. In their theory, Fisbein and Ajzen (1975) indicate that beliefs are shaped in one of two ways: the first is based on experience and observation, and the second is based on information received from other external sources. As per the theory, beliefs lead to attitude formation toward an object. Then, the attitudes formed toward an object leads to a certain intention to behave in a certain way in relation to that object, and eventually behavioral intention leads to actual behavior, as shown in figure 2 .

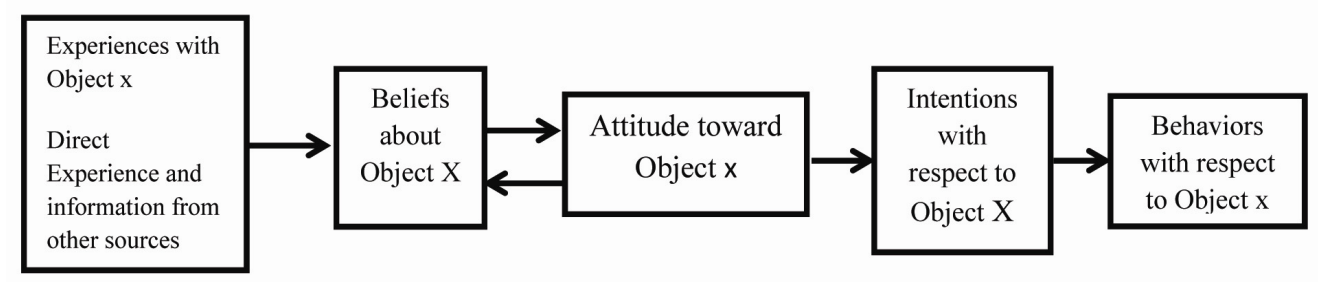

Figure 2. Reasoned-action attitude model

Source: Adapted from Fishbein and Ajzen, 1975.

\section{The Research Proposed Model}

This research focuses on the theory of reasoned action, conceptualizing how relationship marketing activities (experiences that customers have with firms) influence customers' perceptions of the corporate reputation of their respective firms, and, consequently, how that perception of corporate reputation influences their customer loyalty toward such firms, This complex of factors represents both behavioral intention and actual behavior at 
the same time. The antecedent revolves around the way customers experience a relationship marketing activities performed by the firm with which they transact. Corporate reputation manifests as the customers' present perception and attitude toward the firm. The consequences of corporate reputation emerge as behavioral outcomes due to the perceptions of corporate reputation, which are evaluated through customer loyalty, which encompasses the behavioral intention and actual behavior.

As pointed out earlier, the firm's corporate reputation is really shaped over the long term based on the first-hand experiences and observations of how such firms manage their relationships with their customers. This research will focus on the firm's relationship marketing orientation as it manifests in how the customers are indeed experiencing first-hand firm-customer relationship.

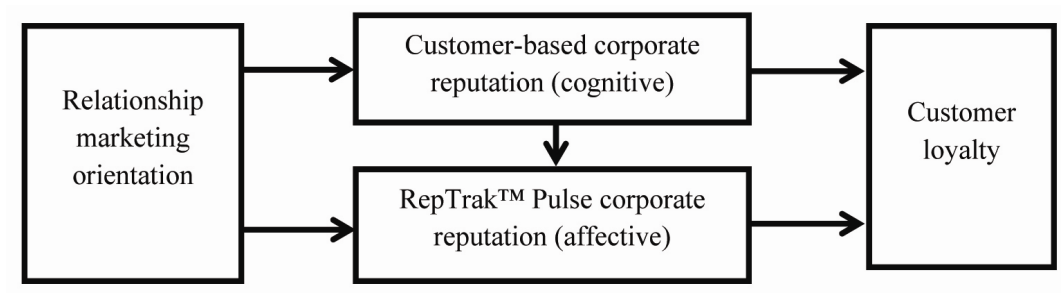

Figure 3. The proposed conceptual model

Nevertheless, it is important to note that definitions of corporate reputation as yet lack complete consensus on its components (Ponzi et al., 2011). This divergence is reflected in the number of suggested measurement scales that vary based on how the construct of corporate reputation is defined. However, it was found that most of the items in such scales were consistently found to load on two factors: the first focuses on an overall measure of how the firm emotionally appealing is, and the second focuses on the cognitive components of the firm's performance (Ponzi et al., 2011). This convergence justifies the use of two measurement scales for corporate reputation in the proposed research model. One scale is a customer-based corporate reputation scale (Walsh \& Beatty, 2007), and the other is the RepTrak ${ }^{\mathrm{TM}}$ Pulse measurement scale. Hence, corporate reputation is considered as a two-dimensional construct, cognitive and affective, as shown in the proposed conceptual model in figure 3.

\section{References}

Abratt, R., \& Kleyn, N. (2012). Corporate Identity, corporate branding and corporate reputations: reconciliation

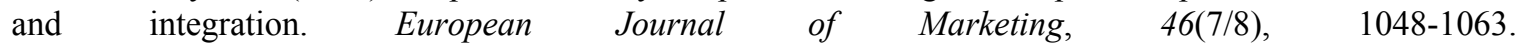
http://dx.doi.org/10.1108/03090561211230197

Ali, R., Lynch, R., Melewar, T. C., \& Jin, Z. (2015). The Moderating Influences on the Relationship of Corporate Reputation with its Antecedents and Consequences: A Meta-analytic Review. Journal of Business Research, 68(5), 1105-1117. http://dx.doi.org/10.1016/j.jbusres.2014.10.013

Argenti, P., \& Druckenmiller, B. (2004). Reputation and the corporate brand. Corporate Reputation Review, 6(4), 368-374. http://dx.doi.org/10.2139/ssrn.387860

Balmer, J. M. T. (1998). Corporate identity and the advent of corporate marketing. Journal of Marketing Management, 14(8), 963-996. http://dx.doi.org/10.1362/026725798784867536

Balmer, J. M. T. (2001). Corporate identity, corporate branding and corporate marketing: seeing through the fog. European Journal of Marketing, 35(3/4), 248-291. http://dx.doi.org/10.1108/03090560110694763

Balmer, J. M. T., \& Greyser, S. A. (2006). Corporate Marketing: Integrating corporate identity, corporate branding, corporate communications, corporate image and corporate reputation. European Journal of Marketing, 40(7/8), 730-741. http://dx.doi.org/10.1108/03090560610669964

Fishbein, M., \& Ajzen, I. (1975). Belief, attitude, intention, and behavior: An introduction to theory and research. Reading, MA: Addison-Wesley.

Fombrun, C. (1996). Reputation: realizing value from the corporate image. Boston: Harvard Business School Press.

Fombrun, C., \& Van Riel, C. (1997). The Reputational landscape. Corporate Reputation Review, 1(1-2), 5-13. http://dx.doi.org/10.1057/palgrave.crr.1540024 
Grunig, J. \& Hung, C. (2002). The effect of relationships on reputation and reputation on relationships: A cognitive, behavioral study. Paper presented at the PRSA Educator's Academy 5th Annual International, Interdisciplinary Public Relations Research Conference, Miami, FL, March 8-10.

Hunt, S. D. (2010). Marketing Theory: Foundations, Controversy, Strategy, Resource-advantage theory. New York. M.E. Sharpe, Inc.

Kim, J. N. \& Rhee, Y. (2011). Strategic thinking about employee communication behavior (ECB) in public relations: Testing the models of megaphoning and scouting effects in Korea. Journal of Public Relations Research, 23(3), 243-268. http://dx.doi.org/10.1080/1062726X.2011.582204

Kim, J. N., Hung-Baesecke, C. F., Yang, S. U., \& Grunig, J. E. (2013). A Strategic Management approach to Reputation, Relationships, and Publics: The Research Heritage of the Excellence Theory. In C. E. Carrol (Ed.), The Handbook of Communication and Corporate Reputation (pp. 197-212). Malden, MA: Wiley-Blackwell. http://dx.doi.org/10.1002/9781118335529.ch18

Money, K., \& Hillenbrand, C. (2006). Using reputation measurement to create value: an analysis and integration of existing measures. Journal of General Management, 32(1), 1-12.

Ponzi, L., Fombrun, C., \& Gardberg, Naomi (2011). RepTrak ${ }^{\mathrm{TM}}$ Pulse: Conceptualizing and Validating a Short-Form Measure of Corporate Reputation. Corporate Reputation Review, 14(1), 15-35. http://dx.doi.org/10.1057/crr.2011.5

Roberts, P. W., \& Dowling G. R. (2002). Corporate reputation and sustained superior financial performance. Strategic Management Journal, 23(12), 1077-1093. http://dx.doi.org/10.1002/smj.274

Tischer, S., \& Hildebrandt, L. (2014). Linking Corporate Reputation and Shareholder Value Using the Publication of Reputation Rankings. Journal of Business Research, 67, 1007-1017. http://dx.doi.org/10.1016/j.jbusres.2013.08.007

Walsh, G., \& Beatty, S., (2007). Customer-based corporate reputation of a service firm: scale development and validation. Journal of the Academy of Marketing Science, 35(1), 127-143. http://link.springer.com/article/10.1007\%2Fs11747-007-0015-7

Walsh, G., \& Wiedmann, K.-P. (2004). A Conceptualization of Corporate Reputation in Germany: An Evaluation and Extension of the RQ. Corporate Reputation Review, 6(4), 304-312. http://dx.doi.org/10.1057/palgrave.crr.1540001

Yang, S.-U. (2007). An integrated model for organization-public relational outcomes, organizational reputation, and their antecedents. Journal of Public Relations Research, 19(2), 91-121. http://dx.doi.org/10.1080/10627260701290612

Yang, S.-U., \& Grunig, J. (2005). Decomposing organizational reputation: The effects of organization-public relationship outcomes on cognitive representations of organizations and evaluations of organizational performance. Journal of Communication Management, 9(4), 305-326. http://dx.doi.org/10.1108/13632540510621623

Zabala, I., Panadero, G., Gallardo, L. M., Amate, C. M., Saanchez-Galindo, M., Tena, I., \& Villalba, I. (2005). Corporate Reputation in Professional Services Firms: Reputation Management Based on Intellectual Capital Management. Corporate Reputation Review, 8(1), 59-71. http://dx.doi.org/10.1057/palgrave.crr.1540239

\section{Copyrights}

Copyright for this article is retained by the author(s), with first publication rights granted to the journal.

This is an open-access article distributed under the terms and conditions of the Creative Commons Attribution license (http://creativecommons.org/licenses/by/3.0/). 